\title{
Habitat associations of juvenile versus adult butterflyfishes
}

\author{
M. S. Pratchett ${ }^{1 *}$, M. L. Berumen ${ }^{2}$, M. J. Marnane ${ }^{1}$, J. V. Eagle ${ }^{1}$, D. J. Pratchett ${ }^{1}$ \\ ${ }^{1}$ ARC Centre of Excellence for Coral Reef Studies, \\ James Cook University, Townsville, Queensland 4811, Australia. \\ ${ }^{2}$ Woods Hole Oceanographic Institution, \\ MS \#50 Woods Hole, MA 02543, USA \\ *Corresponding author: Phone: +61 747815747 \\ Fax: +61747251570 \\ Email: morgan.pratchett@j,ju.edu.au
}

Key words: Coral reefs, Habitat preference, Recruitment, Ontogeny. 


\section{Abstract}

Many coral reef fishes exhibit distinct ontogenetic shifts in habitat use while some species settle directly in adult habitats, but there is not any general explanation to account for these differences in settlement strategies among coral reef fishes. This study compared distribution patterns and habitat associations of juvenile (young of the year) butterflyfishes to those of adult conspecifics. Three species, Chaetodon auriga, Chaetodon melannotus, and Chaetodon vagabundus, all of which have limited reliance on coral for food, exhibited marked differences in habitat association of juvenile versus adult individuals. Juveniles of these species were consistently found in shallow-water habitats, whereas adult conspecifics were widely distributed throughout a range of habitats. Juveniles of seven other species (Chaetodon aureofasciatus, Chaetodon baronessa, Chaetodon citrinellus, Chaetodon lunulatus, Chaetodon plebeius, Chaetodon rainfordi, and Chaetodon trifascialis), all of which feed predominantly on live corals, settled directly into habitat occupied by adult conspecifics. Butterflyfishes with strong reliance on corals appear to be constrained to settle in habitats that provide access to essential prey resources, precluding their use of distinct juvenile habitats. More generalist butterflyfishes, however, appear to utilise distinct juvenile habitats and exhibit marked differences in the distribution of juveniles versus adults. 


\section{Introduction}

Coral reef fishes exhibit striking patterns in their distribution and abundance. Most obvious are marked differences in the abundance of fishes among different reef habitats, e.g., among physiognomic reef zones (Russ 1984), between exposed versus sheltered locations (Choat and Bellwood 1985), or between inshore versus offshore reefs (Williams 1991). Such patterns are often thought to be established at settlement due to spatial variation in larval supply (Hixon and Carr 1997; Doherty 2002) or distinct settlement preferences of larval fishes (Holbrook et al. 2000). However, spatial patterns in the abundance of fishes may also be structured by events and processes occurring after settlement, such as spatial variation in post-settlement survivorship and/ or ontogenetic shifts in patterns of habitat use. For example, Booth (2002) documented significant spatial variation in post-settlement mortality of the ambon damselfish, Pomacentrus amboinensis, which almost completely obscured patterns of abundance established at settlement. Many different coral reef fishes (including haemulids, pomacentrids, labrids, scarids, and serranids) have also been shown to settle in specific juvenile habitats and then later (after weeks to months) recruit to habitats occupied by adult conspecifics (Shulman and Ogden 1987; McCormick and Makey 1997; Nagelkerken et al. 2001; Adams and Ebersole 2002; Lecchini and Galzin 2005). The use of distinct juvenile habitats (i.e., putative nursery habitats, Beck et al. 2001) varies greatly among species within and among families (Lecchini and Galzin 2005), but there is not any general explanation why some fishes utilise distinct juvenile habitats and others do not.

Ontogenetic shifts in habitat use by marine fishes have been variously attributed to: 1) changes in habitat-specific mortality risk associated with increasing body size 
(Gillanders et al. 2003); 2) reducing competition between early juvenile fishes and adult conspecifics (Lirman 1994); or 3) ontogenetic changes in resource requirements and spatial disparities in the availability of these resources (Cocheret de la Morinière et al. 2003a, b). Most coral reef fishes appear to utilise distinct juvenile habitats with high structural complexity or shallow water, presumably because they provide refuge from predators and minimise early post-settlement mortality (Gillanders et al. 2003). However, habitats which provide the best refuge from predators may not necessarily provide best access to optimal prey resources (Harmelin-Vivien 1989), potentially causing significant trade-offs between early post-settlement growth and mortality. Although it has never been tested, coral reef fishes that utilise distinct juvenile habitats may represent species with highly generalised diets that are less constrained by reliance on specific resources (e.g., Nagelkerken et al. 2001). Species with highly specialised diets, meanwhile, may be constrained to settle in habitats that provide access to essential resources. Unless there are distinct differences in resource requirements with ontogeny, this would require settling directly in habitats occupied by adult conspecifics (e.g., Jones 1987). Early establishment of feeding territories may also be fundamental to ensure future resource availability for highly specialised species.

For Chaetodon butterflyfishes (family Chaetodontidae), variation in the abundance and species composition of adult assemblages are typically ascribed to variation in the physical and biological structure of benthic reef habitats (HarmelinVivien and Bouchon-Navaro 1983; Öhman and Rajasuriya 1998; Cadoret et al. 1999; Bozec et al. 2005). For example, many butterflyfishes feed primarily (if not exclusively) on living tissue from scleractinian and alcyonacean corals (Pratchett 2005), and these species are generally more abundant in locations or habitats with greatest availability of prey resources (Findley and Findley 1985; Roberts et al. 1992). Further, declines in 
coral cover, caused by acute disturbance events (e.g., cyclones, coral bleaching, or outbreaks of coral predators) often lead to significant declines in the abundance of coral-feeding butterflyfishes (Bouchon-Navaro et al. 1985; Williams 1986; Pratchett et al. 2006b). Butterflyfishes use coral not only for food, but many species also settle in live coral colonies (e.g., Fowler et al. 1992). Therefore, strong associations between butterflyfishes and corals may be established at settlement, whereby larvae preferentially settle into particular habitats and rarely move after settlement (Berumen et al. 2005).

Butterflyfishes may exhibit one of three different settlement strategies: 1) larval fishes may preferentially settle in habitats or micro-habitats used by adult conspecifics; 2) larval butterflyfishes may settle indiscriminately, but have higher survivorship leading to higher abundance within certain habitats (e.g., habitats with high coral cover); or 3) larvae may preferentially settle in habitats that are markedly different from those habitats or micro-habitats typically used by adult conspecifics (i.e., distinct juvenile habitats) and then move to adult habitats after significant post-settlement growth. Harmelin-Vivien (1989) reported marked inter-specific variation in the settlement strategies of butterflyfishes. For some species, juveniles were generally more abundant in near-shore, shallow water habitats, whereas adults predominated in deeper and more exposed habitats (Harmelin-Vivien 1989). However, juveniles of some species settle directly in habitats occupied by adult conspecifics (Ralston 1981; Harmelin-Vivien 1989; Fowler et al. 1992). Settlement strategies may vary among species depending upon their larval swimming ability (Fisher 2005), ontogenetic shifts in resource requirements (Harmelin-Vivien 1989), competitive ability (Öhman et al. 1998), and/ or predation risk (Almany 2004). 
The purpose of this study was to compare distribution patterns and habitat associations of juvenile (young of the year) butterflyfishes to those of adult conspecifics, testing for ontogenetic shifts in the use of different reef-habitats (e.g., exposed reef crest habitats versus lagoonal habitats). Distributions of juvenile versus adult butterflyfishes were considered for ten species with different diets (Pratchett 2005) and a gradation in dietary specificity (Pratchett 2007). The most specialised species, Chaetodon trifascialis feeds almost exclusively on Acropora hyacinthus (Pratchett 2005) and is found almost exclusively on exposed reef crest habitats dominated by this coral species (Reese 1981). In contrast, Chaetodon vagabundus feeds on a wide variety of different prey, including scleractinian corals, alcyanacean soft corals, polychaetes, copepods and algae (Harmelin-Vivien 1989), and is broadly distributed across a range of different habitats (Berumen and Pratchett 2006). Though Harmelin-Vivien (1989) dismissed links between ontogenetic habitat-shifts and resource specialisation, differences in the distribution of juvenile versus adult butterflyfishes are expected to be most pronounced for species with high dietary versatility, providing increased opportunity to exploit a diversity of prey items and different habitats.

\section{Materials and methods}

This study was conducted during February and March 2004, towards the end of the period of peak recruitment for butterflyfishes in the south-west Pacific (Williams and Sale 1981; Fowler et al. 1992).Variation in the abundance of juvenile butterflyfishes among distinct reef habitats was studied and compared to densities of adult conspecifics within the same reef habitats, where habitats refer to six readily distinguishable areas of reef with distinct geomorphologic and environmental 
conditions, which are also characterised by distinct benthic assemblages, following Mumby and Harborne (1999). Butterflyfishes were categorized as juvenile or adult based on size (juveniles $<50 \mathrm{~mm}$ total length [TL]; adults $>100 \mathrm{~mm}$ TL). These size classes are based on previous observations for Chaetodon lunulatus and Chaetodon melannotus, where the size-specific onset of sexual maturity occurred between 50100mm TL (Pratchett et al. 2006a). Moreover, no individuals were observed in the intervening size class (50-100mm TL), suggesting that all juveniles were from the latest year class, following Berumen (2004).

To examine generalities in habitat-associations of juvenile butterflyfishes over large geographic scales, visual surveys were undertaken (within a 6-week period) across three geographically separated reefs (Lion Island, Lizard Island, and One Tree Island). Lion Island $\left(09^{\circ} 32\right.$ 'S, $\left.147 \mathrm{o} 16^{\prime} \mathrm{E}\right)$ is a small, continental island surrounded by fringing reef, located approximately $2 \mathrm{~km}$ off the southern coast of Papua New Guinea, near the country's capital, Port Moresby. Lizard Island (14 $\left.40^{\circ} \mathrm{S}, 145^{\circ} 27^{\prime} \mathrm{E}\right)$ is located approximately $30 \mathrm{~km}$ off the eastern coast of Australia, in the northern section of the Great Barrier Reef (GBR). Lizard Island is a continental island with extensive fringing reefs that almost completely enclose a large lagoon on the southern side of the island. One Tree Reef $\left(23^{\circ} 30^{\prime} \mathrm{S}, 152^{\circ} 06^{\prime} \mathrm{E}\right)$ is located approximately $70 \mathrm{~km}$ off the eastern coast of Australia, in the southern section of the GBR. One Tree Reef is a small coral cay situated on the south-eastern corner of a large platform reef (ca. $5 \mathrm{~km}$ diameter), which completely encircles a large, shallow lagoon.

\section{Field sampling}

At each of the three geographically separated reefs (Lion Island, Lizard Island, and One Tree Reef), sampling was conducted within 5-6 distinct shallow-water reef 
habitats: 1) the exposed reef crest (ERC); 2) obliquely exposed reef crest (ORC);3) exposed reef flat (ERF); 4) sheltered back reef habitat (SBR); and 5) shallow water patch reefs (SPR) located close (within 100m) to the shoreline (Fig. 1). At Lizard Island and One Tree Reef, where large, semi-enclosed lagoons were present, butterflyfishes were also surveyed along the reef tops of haphazardly selected lagoonal reefs (LAG). These six distinct reef habitats were selected to encompass gradients of exposure and coral cover, and also include habitats (especially back-reefs, shallow water patch reefs, and lagoons) commonly used as distinct juvenile habitats by many coral reef fishes (Adams and Ebersole 2002; Adams et al. 2006). Notably, this study did not consider either mangrove or seagrass habitats (cf., Nagelkerken et al. 2000, 2001) because of the limited availability of these habitats at each of the three reefs. There were small patches of seagrass in the sheltered back reef habitat (SBR) at Lion Island, but the dominant feature of this habitat was the branching coral Montipora digitata.

The abundance of juvenile and adult butterflyfishes within various reef habitats were quantified using transect-based underwater visual census. Surveys were conducted using replicate $50 \times 4 \mathrm{~m}$ belt transects, with 4-5 replicate transects within each habitattype (exposed reef crest, obliquely exposed reef crest, exposed reef flat, back reef crest, shallow water patch reefs, and lagoonal reefs) at each location. Butterflyfishes were surveyed during two passes over each transect. During the first pass, adult butterflyfish within $2 \mathrm{~m}$ of the transect line were counted while simultaneously deploying the transect tape, following Fowler (1990). On the second pass, all coral colonies (within the $4 \mathrm{~m}$ wide belt transect) were carefully searched for the presence of juvenile butterflyfishes. To relate variation in the abundance of butterflyfishes (juveniles and adults) to coral cover and composition, point-intercept sampling was used to sample corals underlying each transect. 100 uniformly spaced points $(50 \mathrm{~cm}$ apart) were sampled along each 
transect. Correlations between the abundance of adult and juvenile butterflyfishes versus percentage coral cover were tested using Pearson's correlation coefficient.

Spatial patterns in the abundance of juvenile versus adult butterflyfishes (among reefs and among habitat types) were analysed using log-linear modelling (Agresti 2002) of a 3-way contingency table (reef $\times$ habitat $\times$ life stage), performed separately for each species. Data were pooled at the transect level to meet minimum numbers of observations. Data from lagoonal habitat (LAG) was examined, but omitted from loglinear analyses to allow for a comparison of Lizard Island and One Tree Reef reefs with Lion Island (where lagoonal habitat did not occur). Log-linear statistics quoted refer to changes in partial statistics (likelihood ratios: $\mathrm{G}^{2}$ ) caused by removing terms from higher order models in a hierarchical set. Analyses were conducted for each of the 10 most abundant species of butterflyfishes (Chaetodon aureofasciatus, Chaetodon auriga, Chaetodon baronessa, Chaetodon citrinellus, C. lunulatus, C. melannotus, Chaetodon plebeius, Chaetodon rainfordi, C. trifascialis, and C. vagabundus). Bonferroni corrected alpha-levels were used to account for increased error rates arising from multiple analyses of non-independent data, following Sokal and Rholf (1987). Excluded from analyses were 9 species (Chaetodon flavirostris, Chaetodon kleinii, Chaetodon lunula, Chaetodon lineolatus, Chaetodon pelewensis, Chaetodon rafflessi, Chaetodon speculum, Chaetodon unimaculatus, and Heniochus varius) for which juveniles were only rarely found during the study. Log-linear modelling was performed using the Statistica $^{\mathrm{TM}}$ v.6.0 statistical package.

\section{Micro-habitat choice experiments}

To assess micro-habitat preferences of juvenile butterflyfishes, multiple-habitat choice experiments were conducted in large flow-through aquaria $(>300 \mathrm{~L}$ capacity 
aquaria) at the Lizard Island and One Tree Island Research Stations. During these experiments, individual butterflyfishes were offered a choice of five different habitats; Acropora divaricata, A. hyacinthus, Pocillopora damicornis, Porites cylindrica, and one dead colony of caespitose Acropora spp. Alternate micro-habitats were approximately equal in size (ca. $20 \mathrm{~cm}$ diameter) and were placed equidistant around the outer edge of the aquaria. The position of each of the five micro-habitats within the aquaria (relative to the water inlet, water out-flow and other micro-habitats) was changed after every trial, and the health of all live corals was confirmed prior to starting each new trial.

Multiple-habitat choice experiments were conducted using juvenile butterflyfishes $(<50 \mathrm{~mm}$ TL) collected from reefs around Lizard Island and One Tree Reef using clove oil and hand nets, following Munday and Wilson (1997). Initial experiments were conducted using naïve pre-settlement butterflyfishes caught in lighttraps, following Öhman et al. (1998). However, light traps yielded very low catches of butterflyfishes $(<0.20$ butterflyfishes per light trap, per night). Further, butterflyfishes caught in light-traps did not exhibit strong affinities with settlement habitats; 5 out of 5 butterflyfishes tested from light-traps spent $>12$ hours swimming around the edge of the aquaria, at the surface. Consequently, this study will only consider results from trials using juvenile butterflyfishes caught on the reef and assumes that prior settlement experience will not bias results from this experiment. To minimise post-settlement experience the smallest (ca. $25 \mathrm{~mm}$ TL) and thus, most recently settled juveniles were selected for use in these experiments. Following capture, butterflyfishes were kept in small glass aquaria for a maximum of 48 hours prior to settlement trials. Micro-habitat choice experiments were conducted using only one butterflyfish in each independent trial (cf. Öhman et al. 1998) to exclude priority effects on micro-habitat choices. 
Priority effects may be important in determining settlement preferences of damselfishes, which may settle en masse (Öhman et al. 1998). However, settlement rates of butterflyfishes are comparatively low (Fowler et al. 1992) and recently settled butterflyfishes are almost always observed on their own. To start each trial, a single butterflyfish was introduced to a vertical holding tube (ca. 10cm diameter), open at each end, and positioned in the centre of the experimental tank. After 5-10 minutes in the holding tube, the fish was released by lifting the tube vertically out of the water. Following release, butterflyfishes were observed for at least 10 minutes, recording the sequence in which they visited and sheltered within alternate micro-habitats. Occupation of the particular micro-habitats was then recorded at intervals of 1 hour, 4-6 hours, and 12-14 hours after release. All trials were initiated at least 4 hours before sunset and were concluded the following morning.

Multiple-habitat choice experiments were conducted for a total 129 individuals, from 17 different species. However, only the 10 most abundant species $(C$. aureofasciatus, C. auriga, C. baronessa, C. citrinellus, C. lunulatus, C. melannotus, C. plebeius, C. rainfordi, C. trifascialis, and C. vagabundus) were collected in sufficient abundance ( $\mathrm{n} \geq 8$ individuals) to enable meaningful analyses of micro-habitat preference. Even with eight or more individuals of each species, it was not possible to analyse micro-habitat selection by treating each of the five micro-habitats separately (as expected frequencies would have been less than five). Therefore, observations were pooled from each of the four least preferred micro-habitats, and a Chi-square goodnessof-fit test was used to examine whether butterflyfishes were observed in the most frequently used micro-habitat type significantly more than all other micro-habitats combined (Table 1). 
Extensive field sampling was used to assess whether results from microhabitatchoice experiments related to field-based patterns of micro-habitat use. During transect based surveys at each of the three geographically separated reefs (Lion Island, Lizard Island, and One Tree Reef), the coral colony with which each juvenile butterflyfish was associated was recorded to species. These observations were further supplemented during systematic surveys at Lizard Island and One Tree Reef, whereby two divers spent a total of 60 minutes searching in each of the six habitat types. Divers recorded the size (TL to the nearest $\mathrm{cm}$ ) and the coral species with which each juvenile was associated. This data provided information on the range of coral species used by each species of butterflyfish, though the number of observations varied greatly among species depending on juvenile densities.

\section{Results}

\section{Distribution and abundance of juvenile butterflyfishes}

A total of 237 juvenile butterflyfishes from 19 species were recorded across 83 transects sampled during this study, corresponding to $2.85 \pm 0.27$ juveniles per $200 \mathrm{~m}^{2}$ (mean $\pm \mathrm{SE}$ ). Among reefs, densities of juvenile butterflyfishes were much higher at Lion Island (4.45 \pm 0.52 juveniles per $200 \mathrm{~m}^{2}$; mean $\pm \mathrm{SE}$ ), compared to Lizard Island $\left(2.35 \pm 0.40\right.$ juveniles per $\left.200 \mathrm{~m}^{2}\right)$ and One Tree Reef $\left(2.34 \pm 0.45\right.$ juveniles per $\left.200 \mathrm{~m}^{2}\right)$. These differences occurred despite the increases in the species richness of butterflyfishes on the latter reefs, where C. rainfordi, C. plebeius, and C. aureofasciatus account for a large proportion of juveniles counted (Fig. 2). The ten most abundant species (C. aureofasciatus, C. auriga, C. baronessa, C. citrinellus, C. lunulatus, C. melannotus, C. plebeius, C. rainfordi, C. trifascialis, and C. vagabundus) accounted for 
$89 \%$ (211/ 237 individuals) of juveniles counted. Consequently, subsequent analyses only consider these ten species.

The abundance of both juvenile and adult butterflyfishes varied greatly among the 6 distinct reef habitats considered in this study (exposed reef crest, obliquely exposed reef crest, exposed reef flat, sheltered back reef, shallow patch reefs, and lagoonal patch reefs), and habitat-associations did not vary among reefs for either of the ten species studied (log-linear statistics: $\Delta \mathrm{G}^{2}=0.20$ to $3.73, \mathrm{p}=0.99$ to 0.09 ). Three (out of ten) species (C. auriga, C. vagabundus, and C. melannotus) exhibited distinct differences in the habitat associations of juveniles relative to adult conspecifics (loglinear statistics: $\Delta \mathrm{G}^{2}=14.84$ to $39.99, \mathrm{p}<0.01$; Fig. 3). For $C$. vagabundus, juveniles were only recorded within lagoon and sheltered patch reef habitats, while adults were commonly recorded from exposed and oblique reef crests, sheltered back reefs, and lagoonal reefs. Very few C. vagabundus adults were recorded from sheltered patch reefs (Fig. 3). Juvenile C. auriga were found almost exclusively on lagoonal and sheltered patch reefs, while adult C. auriga were recorded within all reef habitats (Fig. 3). Similarly, juvenile C. melannotus were recorded in only a restricted range of shallow water habitats, while adults were widespread (Fig. 3). However, for most (7/10 species) butterflyfishes (C. aureofasciatus, C. baronessa, C. citrinellus, C. lunulatus, C. rainfordi, C. plebeius, and C. trifascialis), juveniles were distributed among reef habitats in approximate accordance with adult conspecifics (log-linear statistics: $\Delta \mathrm{G}^{2}=$ 1.53 to $8.77, p=0.82$ to 0.06 Fig. 4). For these species the range of habitats occupied by adults was sometimes greater than the range of habitats where juveniles were recorded, but juveniles were always most abundant in habitats where adults were also most abundant. 


\section{Micro-habitat preferences}

During micro-habitat choice experiments, juveniles of five fish species exhibited strong and consistent selection for specific micro-habitats. Chaetodon baronessa, $C$. citrinellus, and C. trifascialis all exhibited significant preference for A. hyacinthus, with 45-75\% of individuals settling in A. hyacinthus after 12 hours (Table 1). Chaetodon trifascialis exhibited the strongest selection with 9 out of 12 individuals settling on $A$. hyacinthus, while the other 3 individuals settled on A. divaricata. For C. aureofasciatus, 8/18 individuals settled on A. divaricata, while 6 out of 18 selected A. hyacinthus, indicating significant selection for live Acropora, but especially A. divaricata (Table 1). Chaetodon rainfordi exhibited significant preference for P. damicornis (Table 1). Juveniles of the remaining five species, C. lunulatus, C. plebeius, C. auriga, C. melannotus, and C. vagabundus, did not show significant micro-habitat preference, whereby their distribution among micro-habitats after 12 hours was not significantly different from random (Table 1). Also, C. auriga and C. vagabundus were the only butterflyfishes that settled into and remained in the dead coral micro-habitat throughout the course of the experiment. Other butterflyfishes, such as C. trifascialis, which initially sought shelter in the dead coral quickly moved to one of the live corals.

In the field, juveniles for 5 out of 10 species (C. aureofasciatus, C. baronessa, C. lunulatus, C. rainfordi and C. trifascialis) were consistently found in closeassociation with individual coral colonies (Table 2). The remaining species, C. auriga, C. citrinellus, C. melannotus, C. plebeius, and C. vagabundus were also often found living in close association with individual coral colonies, but at least some fishes (up to 43\%) were recorded in areas devoid of corals and exhibited no clear association with live coral (Table 2). The range of coral species used by juvenile butterflyfishes was 
extensive ( 45 species from 7 families), though butterflyfishes tended to be associated mainly with A. hyacinthus, A. muricata, P. damicornis, and branching Montipora (Table 1). Due to low densities of juvenile butterflyfishes, formal tests on micro-habitat selectivity were not possible. However, it was clear that results from micro-habitat choice experiments correspond poorly with field-based patterns of micro-habitat use. For example, juvenile C. baronessa showed strong preference for A. hyacinthus in micro-habitat choice experiments, but were never found living in A. hyacinthus in the field. The only butterflyfishes that exhibited strong and consistent micro-habitats preferences across field studies and aquaria experiments were C. trifascialis (associated with $A$. hyacinthus), and to a lesser extent $C$. aureofasciatus (associated with corymbose and staghorn Acropora spp.) and C. rainfordi (associated with Pocillopora spp.). For these species, it is possible that availability of preferred micro-habitats on the reef had a major influence on their distribution among habitats. Juveniles of C. trifascialis predominated in habitats (ERC and ORC), where A. hyacinthus was most abundant, while juvenile $C$. aureofasciatus were recorded in all but very shallow habitats (SPR and LAG), which reflects the distribution of corymbose and staghorn Acropora spp. Juveniles of C. rainfordi were common in a range of habitats (all except spr), which is consistent with the wide-spread abundance of Pocillopora spp. However, the overall distribution and abundance of juvenile butterflyfishes was poorly correlated with abundance of coral micro-habitats. Notably, there was a significant correlation between total abundance of adult butterflyfishes versus percentage hard coral cover $(r=0.64$, $\mathrm{p}<0.01$ ), but no such relationship was apparent for juvenile butterflyfishes. 


\section{Discussion}

The results of this study suggest that some, but not all, butterflyfishes exhibit ontogenetic differences in habitat-use. Only three species (C. auriga, C. melannotus, and C. vagabundus) exhibited significant differences in the distribution of juveniles versus adults. Notably, these three species were those with the least reliance on scleractinian corals for food (Pratchett 2005), feeding on a wide variety of different prey items, including scleractinian corals, alcyonacean soft corals, and various motile invertebrates (Harmelin-Vivien 1989; Pratchett 2005). Juveniles of C. auriga, C. melannotus, and C. vagabundus were found almost exclusively on shallow patch reefs either very close to shore or within the lagoon. These habitats had very limited $(<30 \%)$ cover of scleractinian corals and were dominated by the branching coral $M$. digitata. Moreover, it was in these shallow-water fields of branching $M$. digitata that the only juveniles of several other non-coral feeding butterflyfishes (C. lineolatus, C. ulientensis, and C. flavirostris) were recorded.

Despite the restricted and specific habitats occupied by juveniles, adult $C$. auriga, C. melannotus, and C. vagabundus were distributed across a broad range of different habitats. These marked ontogenetic differences in patterns of habitat use suggest that these butterflyfishes utilise certain habitats (e.g., lagoonal and near-shore patch reefs) as distinct juvenile habitats and disperse to other habitats as they attain adult size (Harmelin-Vivien 1989). The tendency for coral reef fishes to use lagoonal and near-shore patch reefs as distinct juvenile habitats has been reported for a wide range of coral reef fishes (e.g., Nagelkerken et al. 2000; Adams and Ebersole 2002), and is typically ascribed to low levels of predation within these habitats (Hixon 1991; Adams and Ebersole 2002). An alternative explanation for ontogenetic habitat-shifts in 
butterflyfishes relates to ontogenetic shifts in dietary composition, whereby facultative corallivores initially feed mostly on polychaetes, but then consume increasing quantities of coral as they grow and mature (Harmelin-Vivien 1989). Such changes in dietary composition conform with observed shifts away from shallow patch reefs to deeper more exposed habitats and the stronger associations with scleractinian corals among adult butterflyfishes, compared to juvenile butterflyfishes, though it is not clear whether ontogenetic changes in diet are the cause or consequence of habitat-shifts.

Distributions of juveniles versus adults for the remaining seven species (C. aureofasciatus, C. baronessa, C. citrinellus, C. lunulatus, C. plebeius, C. rainfordi, and C. trifascialis) were not significantly different. Notably, all these species feed predominantly on scleractinian corals (Pratchett 2005) and coral-feeding butterflyfishes begin feeding on scleractinian corals immediately after settlement (Harmelin-Vivien 1989). Therefore, these species are expected to settle preferentially in habitats with the greatest availability of preferred corals. Moreover, juveniles of highly selective corallivores (e.g., C. trifascialis and C. baronessa, Pratchett 2005) were restricted to fewer habitat-types compared to more generalist corallivores (e.g., C. plebeius and C. rainfordi, Pratchett 2005). This result was most apparent for C. trifascialis, which is among the most selective of coral-feeding butterflyfishes (Pratchett 2007). Adult $C$. trifascialis feed almost exclusively on A. hyacinthus (Reese 1981; Irons 1989; Pratchett 2005) and accordingly, both juveniles and adults were most abundant on exposed reef crests and obliquely exposed reef crests where A. hyacinthus predominates (Fig. 3). Chaetodon baronessa also feeds mainly on A. hyacinthus when available (Berumen et al. 2005; Pratchett 2005), but juveniles of C. baronessa were relatively rare on exposed reef crest habitats. Depending on their competitive ability, juvenile butterflyfishes may settle in habitats with high abundance of preferred corals, and/ or low abundance of 
potential competitors. Complementary distributions of juvenile $C$. trifascialis and $C$. baronessa are consistent with high levels of dietary overlap (Pratchett 2005) and strong inter-specific competition (Berumen and Pratchett 2006) between these species.

While juvenile coral-feeding butterflyfishes were most abundant in habitats occupied by adult conspecifics, this study does not establish whether butterflyfishes preferentially settle in these habitats (e.g., Fowler 1990), or settle indiscriminately among habitats and have higher survival in optimal habitats (e.g., Booth 2002). Further, it is unclear whether butterflyfishes consistently settle in certain habitats leading to high abundance of adults in these habitats, or if these species settle preferentially in the presence of adult conspecifics, as shown for other coral reef fishes (Sweatman 1983). Results from this study neither support nor refute the notion that butterflyfishes use the presence of adult conspecifics as a settlement cue. Natural selection would impose strong selection for species that preferentially settle in habitats where they have highest survivorship, and the presence of adults is a compelling indicator as to the suitability of the habitat. Irrespective of the actual settlement cues, it appears that juvenile butterflyfishes do discriminate among reef habitats. Larval butterflyfishes are very capable swimmers (Stobutzki and Bellwood 1997; Fisher 2005), and have welldeveloped sensory abilities to select suitable habitats (Leis and Carson-Ewart 2003). It is clear, however, that coral-feeding butterflyfishes are not restricted to only the most optimal habitats. Berumen et al. (2005) showed that densities of C. baronessa and $C$. lunulatus, both of which are obligate coral-feeding butterflyfishes, are very similar between front-reef and back-reef habitats, despite a two-fold difference in the abundance of scleractinian corals (see also Bell et al. 1985; Roberts and Ormond 1987). Habitats with moderate levels of coral cover may still provide appropriate cues and necessary resources for newly-settling fishes, even though these fishes ultimately fare 
much better in habitats with highest coral cover (Berumen et al. 2005). Even if optimal habitats are not saturated, strong inter- and intra-specific competition may force some individuals to settle in marginal or sub-optimal habitats (Munday 2001).

Habitat associations of juvenile butterflyfishes may be partly attributable to micro-habitat preferences for specific live corals, whereby half of the species $(C$. aureofasciatus, C. baronessa, C. citrinellus, C. rainfordi, and C. trifascialis) exhibited significant micro-habitat preferences in aquaria experiments. Also, in the field, virtually all species (all except $C$. auriga and $C$. vagabundus) were predominantly found in just 1 or 2 different coral species. However, there was limited concordance between results of the aquaria experiments and micro-habitat associations in the field. In micro-habitat choice experiments, butterflyfishes choose among micro-habitats independent of differences in surrounding habitat and in the absence of potential competitors and predators. In the field however, there may be a much greater range of factors that influence and constrain micro-habitat use. For example, in micro-habitat choice experiments, C. baronessa showed significant preference for A. hyacinthus but is rarely found in this habitat in the wild, possibly due to strong inter-specific competition with C. trifascialis (Berumen and Pratchett 2006), whereby adult and juvenile C. trifascialis are very aggressive towards juvenile $C$. baronessa. The only butterflyfishes that exhibited consistent micro-habitat preferences across field studies and aquaria experiments were C. trifascialis, and to a lesser extent, C. aureofasciatus and C. rainfordi. Chaetodon trifascialis is well known for being highly specialised (Reese 1981; Irons 1989; Pratchett 2005) and clearly, its strong dependence on A. hyacinthus for food dictates both micro-habitat preferences and juvenile distributions. Similarly, micro-habitat preferences of C. aureofasciatus and C. rainfordi (for Acropora 
divaricata and Pocillopora damicornis, respectively) correspond with their reported feeding preferences (Pratchett 2007).

In conclusion, this study shows that butterflyfishes with lowest reliance on corals and the broadest range of dietary items (C. auriga, C. melannotus, and C. vagabundus) exhibited distinct patterns of habitat-use between juveniles versus adults. In contrast, juveniles of species that feed predominantly on scleractinian corals $(C$. aureofasciatus, C. baronessa, C. citrinellus, C. lunulatus, C. plebeius, C. rainfordi, and C. trifascialis) were most abundant in habitats occupied by conspecific adults. Variation in patterns of habitat-use among conspecific butterflyfishes appear to reflect contrasting levels of dietary specificity, whereby the distribution and abundance of suitable food resources may greatly restrict the range of habitats in which species with very specific feeding requirements can ultimately settle and survive, as was originally proposed by Harmelin-Vivien (1989). Moreover, habitat associations of juvenile butterflyfishes were very similar among reefs separated by more than $600 \mathrm{~km}$, suggesting that butterflyfishes consistently settle within specific reef habitats, leading to highly predictable patterns in the distribution of butterflyfishes among habitats (e.g., Booth et al. 2000). These results highlight the importance of ecological versatility in limiting the distribution and abundance of coral reef fishes.

\section{ACKNOWLEDGMENTS}

This research was funded by a JCU Program Grant to MSP, while MLB was supported by an NSF (USA) Graduate Research Fellowship. This project benefited greatly from logistic support provided by staff at Motupore Island Research Centre, Lizard Island Research Station, and One Tree Island Research Station. 


\section{REFERENCES}

Adams AJ, Ebersole JP (2002) Use of back-reef and lagoon habitats by coral reef fishes. Mar Ecol Prog Ser 228:213-226

Adams AJ, Dahlgren CP, Kellison GT, Kendall MS, Layman CA, Ley JA, Nagelkerken I, Serafy JE (2006) Nursery function of tropical back-reef systems. Mar Ecol Prog Ser 318:287-301

Agresti A (2002) Categorical data analysis. John Wiley and Sons, New York

Almany GR (2004) Differential effects of habitat complexity, predators and competitors on abundance of juvenile and adult coral reef fishes. Oecologia 141:105-113

Beck MW, Heck KL, Able KW, Childers DL, Eggleston DB, Gillanders BM, Halpern B, Hays CG, Hoshino K, Minello TJ, Orth RJ, Sheridan PF, Weistein MP (2001) The identification, conservation and management of estuarine and marine nurseries for fish and invertebrates. BioScience 51:633-641

Bell JD, Harmelin-Vivien M, Galzin R (1985) Large scale spatial variation in abundance in butterflyfishes (Chaetodontidae) on Polynesian reefs. Proc 5th Int Coral Reef Symp 5:421-426

Berumen ML (2004) The importance of juveniles in modelling growth: butterflyfish at Lizard Island. Environ Biol Fish 72:409-413

Berumen ML, Pratchett MS (2006) Effects of resource availability on the competitive behaviour of butterflyfishes (Chaetodontidae). Proc 10th Int Coral Reef Symp 1:644-650

Berumen ML, Pratchett MS, McCormick MI (2005) Within-reef differences in diet and body condition of coral-feeding butterflyfishes (Chaetodontidae). Mar Ecol Prog Ser 287:217-227

Booth DJ (2002) Distribution changes after settlement in 6 species of damselfish (Pomacentridae) in One Tree Island lagoon, Great Barrier Reef. Mar Ecol Prog Ser 226:157-164

Booth DJ, Kingsford MJ, Doherty PJ, Beretta GA (2000) Recruitment of damselfishes in One Tree Island lagoon: persistent interannual spatial patterns. Mar Ecol Prog Ser 202:219-230

Bouchon-Navaro Y, Bouchon C, Harmelin-Vivien ML (1985) Impact of coral degradation on a Chaetodontid fish assemblage (Moorea, French Polynesia). Proc 5th Int Coral Reef Symp 5:427432

Bozec YM, Doledec S, Kulbicki M (2005) An analysis of fish-habitat associations on disturbed coral reefs: chaetodontid fishes in New Caledonia. J Fish Biol 66:966-982

Cadoret L, Aderjoud M, Tsuchiya M (1999) Spatial distribution of chaetodontid fish in coral reefs of the Ryukyu Islands, southern Japan. J Mar Biol Assoc UK 79:725-735

Choat JH, Bellwood DR (1985) Interactions among herbivorous fishes on a coral reef: influence of spatial variation. Mar Biol 89:221-234

Cocheret de la Morinière E, Pollux BJA, Nagelkerken I, Hemminga MA, Huiskes AHL, van der Velde G (2003a) Ontogenetic dietary changes of coral reef fishes in the mangrove-seagrass-reef continuum: stable isotopes and gut-content analysis. Mar Ecol Prog Ser 246:279-289

Cocheret de la Morinière E, Pollux BJA, Nagelkerken I, van der Velde G (2003b) Diet shifts of Caribbean grunts (Haemulidae) and snappers (Lutjanidae) and the relation with nursery-to-coral reef migrations. Estuar Coast Shelf Sci 57:1079-1089

Doherty PJ (2002) Variable replenishment and the dynamics of reef fish populations. In: Sale PF (ed) Coral reef fishes: dynamics and diversity in a complex ecosystem. Academic Press, San Diego, pp 327-358

Findley JS, Findley MT (1985) A search for pattern in butterflyfish communities. Am Nat 126:800-816

Fisher R (2005) Swimming speeds of larval coral reef fishes: impacts on self-recruitment and dispersal. Mar Ecol Prog Ser 285:223-232

Fowler AJ (1990) Spatial and temporal patterns of distribution and abundance of chaetodontid fishes at One Tree Reef, southern GBR. Mar Ecol Prog Ser 64:39-53

Fowler A, Doherty P, Williams D (1992) Multi-scale analysis of recruitment of a coral reef fish on the Great Barrier. Mar Ecol Prog Ser 82:131-141

Gillanders BM, Able KW, Brown JA, Eggleston DB, Sheridan PF (2003) Evidence of connectivity between juvenile and adult habitats for mobile marine fauna: an important component of nurseries. Mar Ecol Prog Ser 247:281-295

Harmelin-Vivien ML (1989) Implications of feeding specialization on the recruitment processes and community structure of butterflyfishes. Environ Biol Fish 25:101-110

Harmelin-Vivien ML, Bouchon-Navaro Y (1983) Feeding diets and significance of coral feeding among Chaetodontid fishes in Moorea (French Polynesia). Coral Reefs 2:119-127 
Hixon MA (1991) Predation as a process structuring coral reef fish communities. In: Sale PF (ed), Coral reef fishes: dynamics and diversity in a complex ecosystem. Academic Press, San Diego, pp 475508

Hixon MA, Carr MH (1997) Synergistic predation, density dependence, and population regulation in marine fish. Science 277:946-949

Holbrook SJ, Forrester GE, Schmitt RJ (2000) Spatial patterns in abundance of a damselfish reflect availability of suitable habitat. Oecologia 122:109-120

Irons DK (1989) Temporal and areal feeding behaviour of the butterflyfish, Chaetodon trifascialis, at Johnston Atoll. Environ Biol Fish 25:187-193

Jones GP (1987) Competitive interactions among adults and juveniles in a coral reef fish. Ecology 68:1534-1547

Lecchini D, Galzin R (2005) Spatial repartition and ontogenetic shifts in habitat use by coral reef fishes (Moorea, French Polynesia). Mar Biol 147:47-58

Leis JM, Carson-Ewart BM (2003) Orientation of pelagic larvae of coral-reef fishes in the ocean. Mar Ecol Prog Ser 252:239-253

Lirman D (1994) Ontogenetic shifts in habitat preferences in the three-spot damselfish, Stegastes planifrons (Cuvier), in Roatan Island, Hondurus. J Exp Mar Biol Ecol 180:71-81

McCormick MI, Makey LJ (1997) Post-settlment transition in coral reef fishes: overlooked complexity in niche shifts. Mar Ecol Prog Ser 153:247-257

Mumby PJ, Harborne AR (1999) Development of a systematic classification scheme of marine habitats to facilitate regional management and mapping of Caribbean coral reefs. Biol Conserv 88:155-163

Munday PL (2001) Fitness consequences of habitat use and competition among coral-dwelling fishes. Oecologia 128:585-593

Munday PL, Wilson SK (1997) Comparative efficacy of clove oil and other chemicals in anaesthetization of Pomacentrus amboinensis, a coral reef fish. J Fish Biol 51:931-938

Nagelkerken I, Kleijnen S, Klop T, van den Brand RACJ, Cocheret de la Morinière E, van der Velde G (2001) Dependence of Caribbean reef fishes on mangroves and seagrass beds as nursery habitats: a comparison of fish faunas between bays with and without mangroves/seagrass beds. Mar Ecol Prog Ser 214:225-235

Nagelkerken I, van der Velde G, Gorisse MW, Meijer GJ, van Hof T, den Hartog C (2000) Importance of mangroves, seagrass beds and the shallow coral reef as a nursery for important coral reef fishes, using a visual census technique. Estuar Coat Shelf Sci 51:31-44

Öhman MC, Rajasuriya A (1998) Relationships between habitat structure and fish communities on coral and sandstone reefs. Environ Biol Fish 53:19-31

Öhman MC, Munday PL, Jones GP, Caley MJ (1998) Settlement strategies and distribution patterns of coral-reef fishes. J Exp Mar Biol Ecol 225:219-238

Pratchett MS (2005) Dietary overlap among coral-feeding butterflyfishes (Chaetodontidae) at Lizard Island, northern Great Barrier Reef. Mar Biol 148:373-382

Pratchett MS (2007) Dietary selection by coral-feeding butterflyfishes (Chaetodontidae) on the Great Barrier Reef, Australia. Raffles Bull Zool Suppl 14:S161-S166

Pratchett MS, Pradjakusuma OA, Jones GP (2006a) Is there a reproductive basis to solitary living versus pair-formation in coral reef fishes? Coral Reefs 25: 85-92

Pratchett MS, Wilson SK, Baird AH (2006b) Declines in the abundance of Chaetodon butterflyfishes following extensive coral depletion. J Fish Biol 69:1269-1280

Ralston S (1981) Aspects of the reproductive biology and feeding ecology of Chaetodon milliaris, a Hawaiian endemic butterflyfish. Environ Biol Fish 6:167-176

Reese ES (1981) Predation on corals by fishes of the family Chaetodontidae: implications for conservation and management of coral reef ecosystems. Bull Mar Sci 31:594-604

Roberts CM, Ormond RFG (1987) Habitat complexity and coral reef fish diversity and abundance on Red Sea fringing reefs. Mar Ecol Prog Ser 41:1-6

Roberts CM, Dawson Shepherd AR, Ormond RFG (1992) Large-scale variation in assemblage structure of Red Sea butterflyfishes and angelfishes. J Biogeogr 19:239-250

Russ GR (1984) Distribution and abundance of herbivorous grazing fishes in the central Great Barrier Reef II. Patterns of zonation of mid-shelf and outer-shelf reefs. Mar Ecol Prog Ser 20:35-44

Shulman MJ, Ogden JC (1987) What controls tropical reef fish populations: recruitment or benthic mortality? An example in the Caribbean reef fish Haemulon flavolineatum. Mar Ecol Prog Ser 39:233-242

Sokal RR, Rholf FJ (1987) Introduction to biostatistics. WH Freeman and Company, New York 
Stobutzki IC, Bellwood DR (1997) Sustained swimming abilities of late pelagic stage coral reef fishes. Mar Ecol Prog Ser 149:35-41

Sweatman HPA (1983) Influence of conspecifics on choice of settlement sites by larvae of two pomacentrid fishes (Dascyllus aruanus and D. reticulatus) on coral reefs. Mar Biol 75:225-229

Victor BC (1986) Larval settlement and juvenile mortality in a recruitment-limited coral reef fish population. Ecol Monogr 56:145-160

Warner RR, Chesson PL (1985) Coexistence mediated by recruitment fluctuations: a field guide to the storage effect. Am Nat 125:769-787

Williams AH, Sale PF (1981) Spatial and temporal patterns of recruitment of juvenile coral reef fishes to coral habitats within "One Tree Lagoon", Great Barrier Reef. Mar Biol 65:245-253

Williams DM (1986) Temporal variation in the structure of reef slope fish communities (central Great Barrier Reef): short term effects of Acanthaster planci infestation. Mar Ecol Prog Ser 28:157-164

Williams DM (1991) Patterns and processes in the distribution of coral reef fishes. In: Sale PF (ed) The ecology of fishes on coral reefs. Academic Press, San Diego, pp 437-474 


\section{Figure Legends}

Figure 1. Map showing locations sampled ( $\mathbf{\square}$ - sampling site, ERC - exposed reef crest, ORC - obliquely exposed reef crest, ERF - exposed reef flat, SBR - sheltered backreef, LAG - lagoon, SPR - shallow patch reefs), within the three sampling sites: Lion Island Papua New Guinea (PNG), Lizard Island and One Tree Reef.

Figure 2. Chaetodon butterflyfishes. Mean abundance ( $\pm \mathrm{SE}$ ) of juvenile butterflyfishes at each reef. Data was pooled across all reef habitats to show large-scale differences in occurrence and abundance of the ten most abundant species.

Figure 3. Chaetodon butterflyfishes. Mean abundance ( $\pm \mathrm{SE}$ ) of adults (clear bars) versus juveniles (shaded bars) for the 10 most commonly recorded butterflyfishes, within each of six distinct reef habitats (ERC, the exposed reef crest; ORC, obliquely exposed reef crest; ERF, exposed reef flat; SBR, sheltered back reef habitat; SPR, shallow water patch reefs; LAG, lagoonal reefs), averaged across the three locations, Lion Island, Lizard Island and One Tree Reef. Statistics quoted refer to changes in partial statistics (likelihood ratios: $\mathrm{G}^{2}$ ) caused by removing terms (habitat x life stage) from higher order models in a hierarchical set. Species are ordered alphabetically with broad feeding guilds (HC, Hard coral feeders; NC, Non hard-coral feeders). 
Figure 1

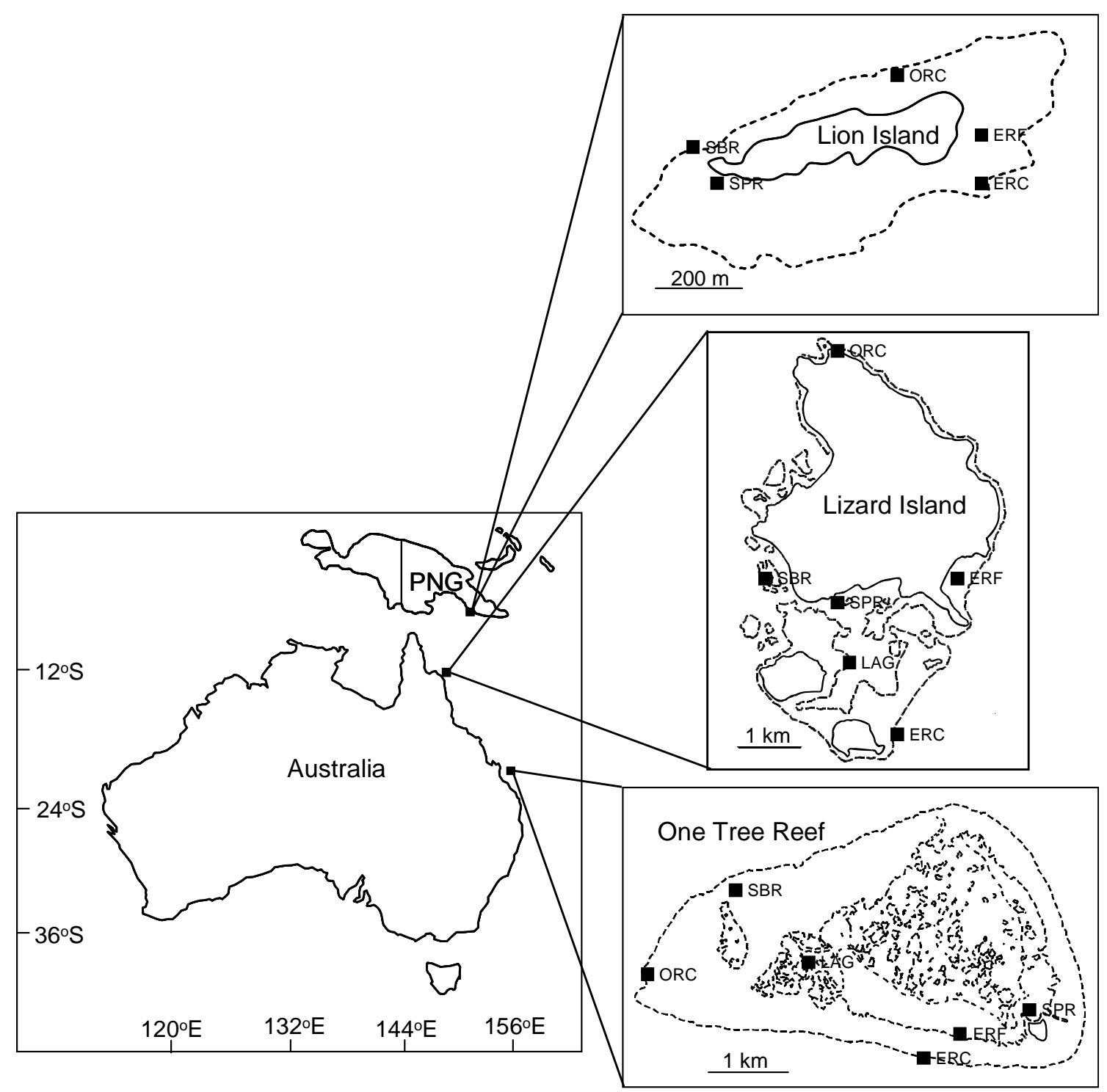


Figure 2 
a) Lion Island

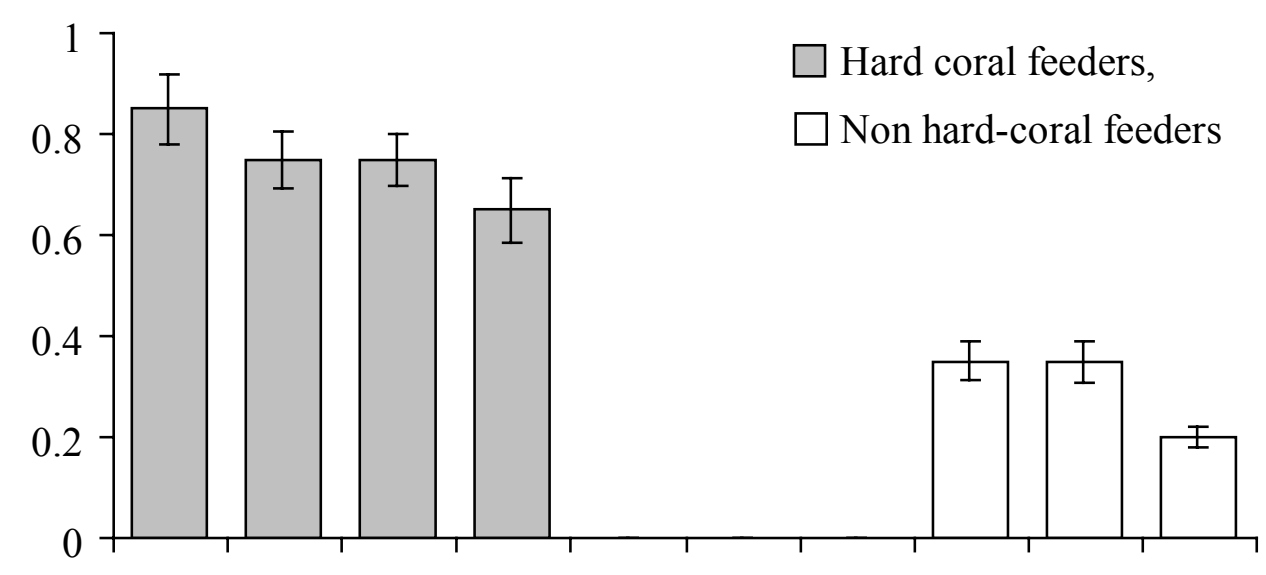

b) Lizard Island

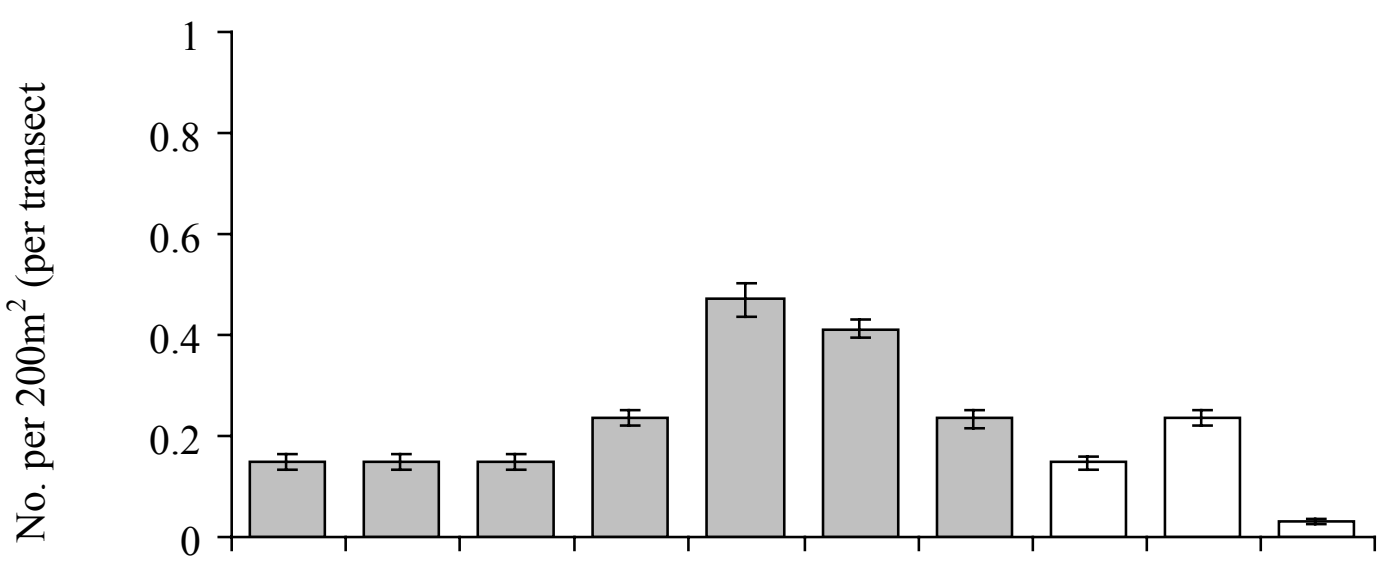

c) One Tree Reef

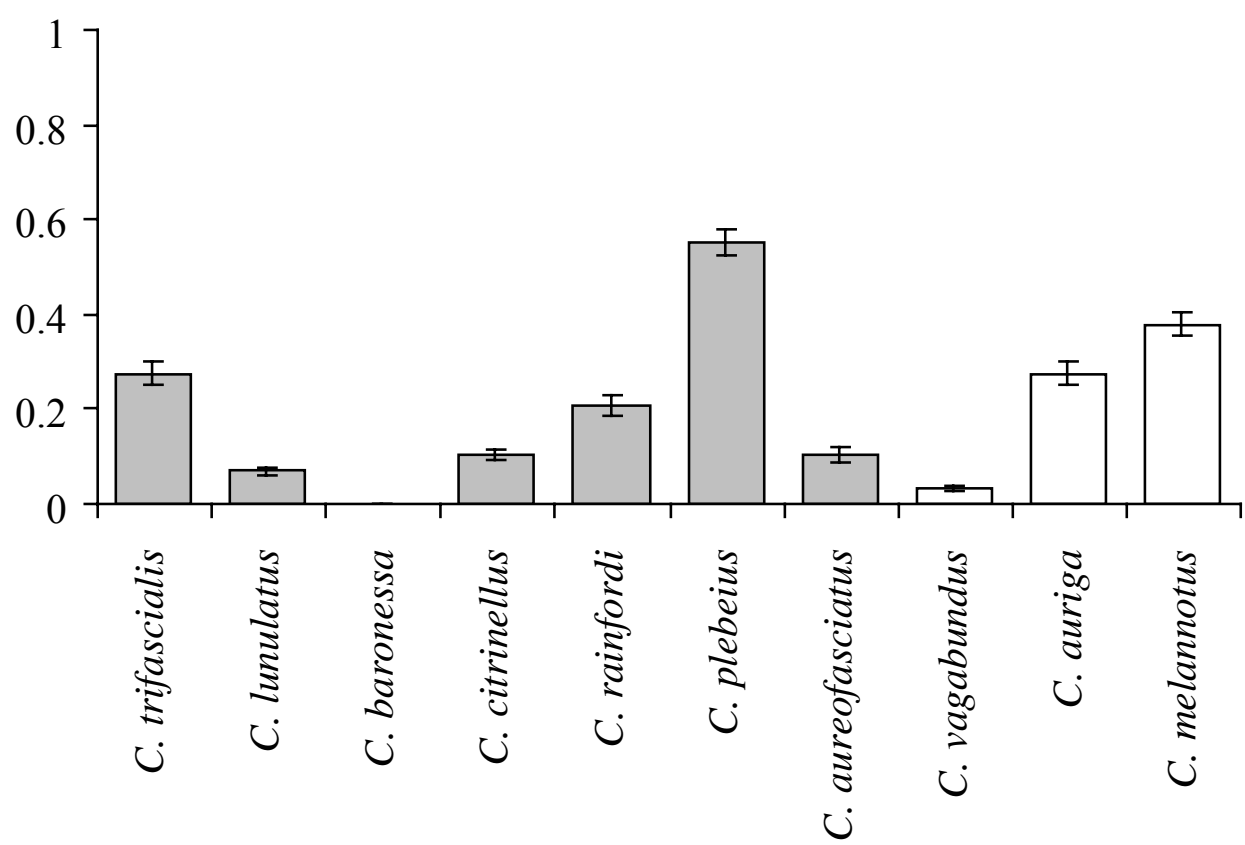


Figure 3 
a C. aureofasciatus (HC) $\Delta \mathrm{G}^{2}=3.01, \mathrm{p}=0.56$

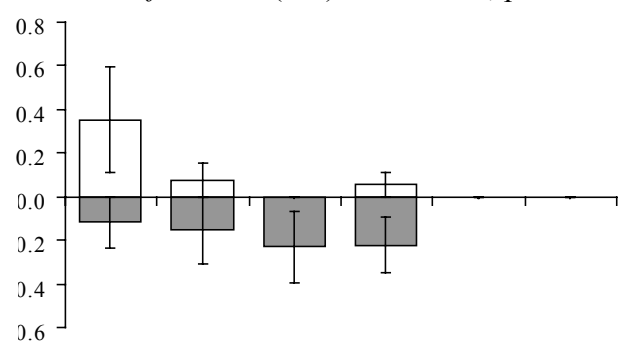

c C. citrinellus (HC) $\Delta \mathrm{G}^{2}=2.37, \mathrm{p}=0.67$
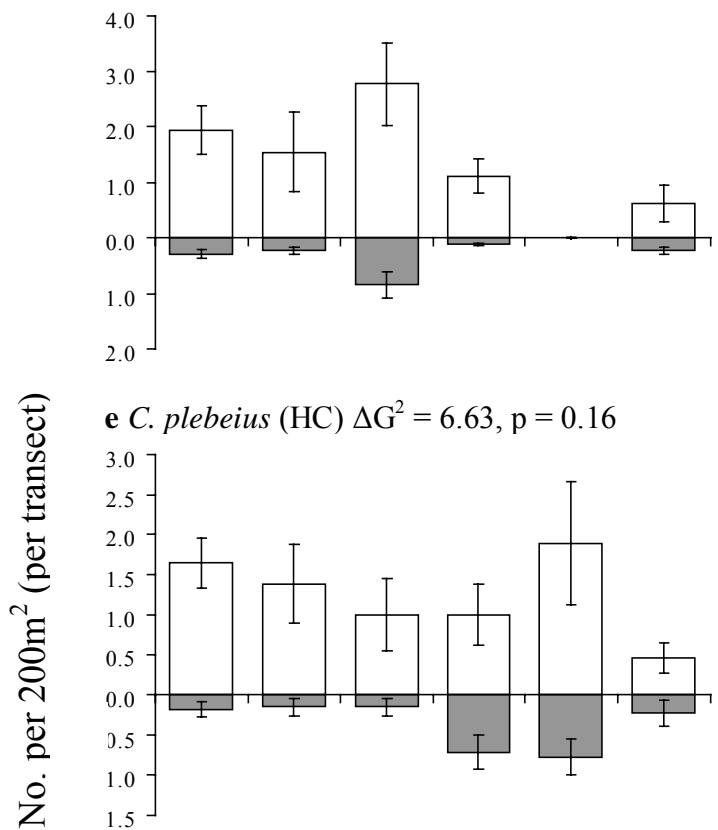

g C. trifascialis (HC) $\Delta \mathrm{G}^{2}=8.77, \mathrm{p}=0.06$

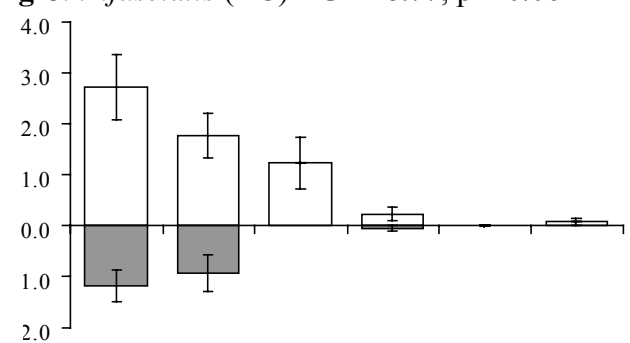

b C. baronessa (HC) $\Delta \mathrm{G}^{2}=1.53, \mathrm{p}=0.82$

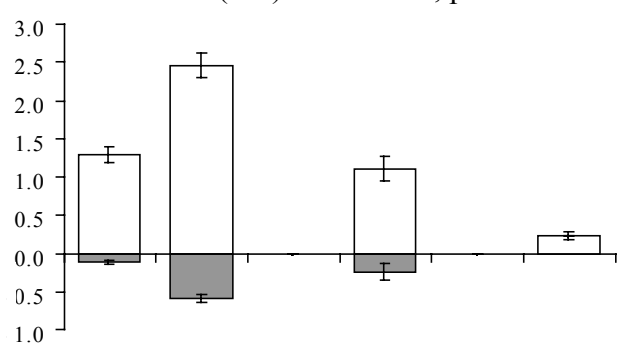

d C. lunulatus (HC) $\Delta \mathrm{G}^{2}=3.66, \mathrm{p}=0.45$

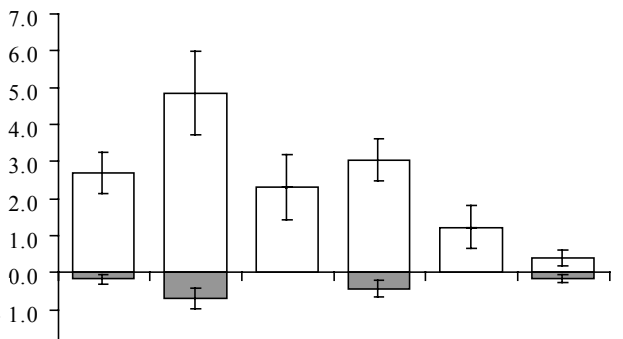

2.0

f C. rainfordi $(\mathrm{HC}) \Delta \mathrm{G}^{2}=3.29, \mathrm{p}=0.51$

2.5

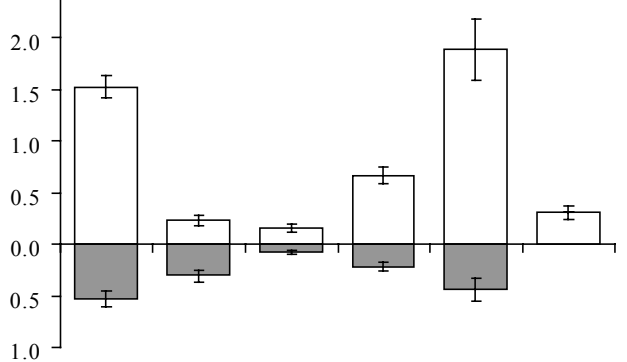

h C. auriga (NC) $\Delta \mathrm{G}^{2}=14.84, \mathrm{p}<0.01$

3.0

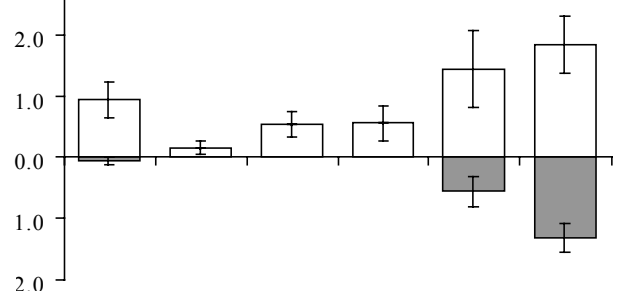


Table 1. Micro-habitat preferences for juveniles of 10 species of butterflyfishes assessed under experimental conditions with equal availability of five different micro-habitats; Acropora divaricata, Acropora hyacinthus, Pocillopora damicornis, Porites cylindrica and Dead Acropora. $P_{m a x}$ is the proportion of individuals that occupied the most frequently used micro-habitat 1 hour, 4-6 hours, and 12-14 hours after release. ${ }^{*}=$ $\mathrm{p}<0.05, * *=\mathrm{p}<0.01 ; * * *=\mathrm{p}<0.001$.

\begin{tabular}{|c|c|c|c|c|c|c|c|c|c|}
\hline \multirow[t]{2}{*}{ Species } & \multirow[t]{2}{*}{$n$} & \multirow[t]{2}{*}{ Model } & \multicolumn{2}{|c|}{$<1$ hour } & \multicolumn{2}{|c|}{ 4-6 hours } & \multicolumn{2}{|c|}{$>12$ hours } & \multirow{2}{*}{$\begin{array}{l}\text { Preferred micro- } \\
\text { habitat }\end{array}$} \\
\hline & & & $P_{\max }$ & $\chi^{2}$ & $P_{\max }$ & $\chi^{2}$ & $P_{\max }$ & $\chi^{2}$ & \\
\hline Chaetodon aureofasciatus & 18 & A. divaricata $>$ Others & 0.29 & 0.13 & 0.35 & 2.48 & 0.44 & $6.72 * *$ & A. divaricata \\
\hline Chaetodon baronessa & 9 & A. hyacinthus $>$ Others & 0.36 & 1.84 & 0.45 & $4.45^{*}$ & 0.45 & $4.45^{*}$ & A. hyacinthus \\
\hline Chaetodon citrinellus & 11 & A. hyacinthus $>$ Others & 0.36 & 1.84 & 0.55 & $8.20 * * *$ & 0.45 & $4.45^{*}$ & A. hyacinthus \\
\hline Chaetodon lunulatus & 11 & A. hyacinthus $>$ Others & 0.36 & 0.03 & 0.27 & 0.03 & 0.27 & 0.36 & - \\
\hline Chaetodon plebeius & 9 & P. damicornis $>$ Others & 0.33 & 0.03 & 0.33 & 0.03 & 0.44 & 3.36 & - \\
\hline Chaetodon rainfordi & 25 & P. damicornis $>$ Others & 0.40 & $6.25 * *$ & 0.44 & $9.00 * * *$ & 0.40 & $6.25 * *$ & P. damicornis \\
\hline Chaetodon trifascialis & 12 & A. hyacinthus $>$ Others & 0.33 & 1.33 & 0.50 & $6.75^{* *}$ & 0.75 & $11.02 * * *$ & A. hyacinthus \\
\hline Chaetodon auriga & 12 & A. hyacinthus $>$ Others & 0.50 & $6.75^{* *}$ & 0.33 & 1.33 & 0.42 & 3.52 & - \\
\hline Chaetodon melannotus & 8 & P. damicornis $>$ Others & 0.38 & 1.53 & 0.38 & 1.53 & 0.38 & 1.53 & - \\
\hline Chaetodon vagabundus & 8 & Dead Acropora $>$ Others & 0.38 & 1.53 & 0.38 & 1.53 & 0.38 & 0.12 & - \\
\hline
\end{tabular}


Table 2. Proportional use of different micro-habitats by butterflyfishes in the field. Data is pooled across habitats and reefs. $n$ is the total number of juveniles for which microhabitat use was recorded. Numbers in bold indicate the most frequently used microhabitat for each butterflyfish.

\begin{tabular}{|c|c|c|c|c|c|c|c|c|c|c|c|}
\hline Species & $n$ & 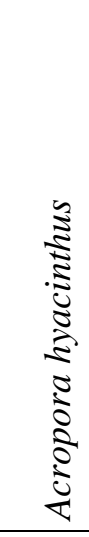 & 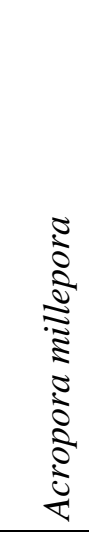 & 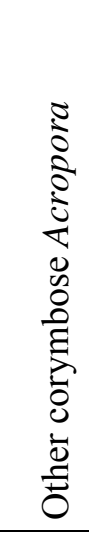 & 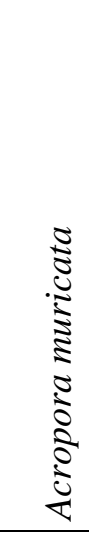 & 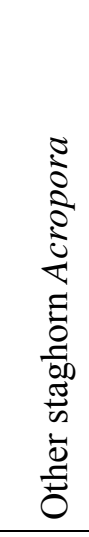 & 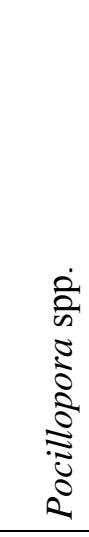 & 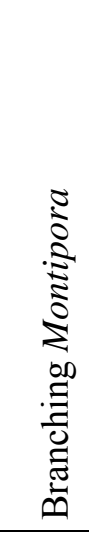 & 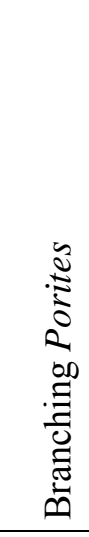 & 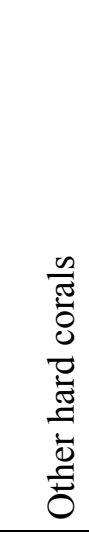 & 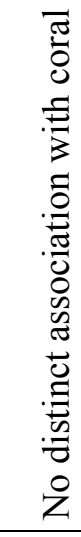 \\
\hline Chaetodon trifascialis & 61 & 0.61 & & 0.07 & 0.21 & 0.11 & & & & & \\
\hline Chaetodon rainfordi & 58 & 0.10 & 0.03 & 0.17 & & 0.26 & 0.36 & & 0.02 & 0.05 & \\
\hline Chaetodon plebeius & 32 & & 0.03 & 0.09 & 0.38 & 0.28 & 0.13 & & & & 0.09 \\
\hline Chaetodon citrinellus & 31 & 0.10 & 0.10 & & 0.35 & & 0.06 & & & 0.26 & 0.13 \\
\hline Chaetodon lunulatus & 29 & & & 0.07 & 0.07 & 0.07 & 0.17 & 0.03 & 0.24 & 0.34 & \\
\hline Chaetodon melannotus & 28 & & & 0.07 & 0.07 & 0.07 & & 0.25 & 0.11 & 0.11 & 0.32 \\
\hline Chaetodon baronessa & 27 & & 0.15 & 0.33 & 0.15 & 0.33 & & & & 0.04 & \\
\hline Chaetodon auriga & 23 & & 0.17 & 0.13 & & & & 0.09 & 0.09 & 0.04 & 0.43 \\
\hline Chaetodon aureofasciatus & 13 & 0.15 & & 0.31 & 0.08 & 0.23 & 0.23 & & & & \\
\hline Chaetodon vagabundus & 12 & & 0.33 & 0.17 & 0.08 & & & & & & 0.42 \\
\hline
\end{tabular}

